\title{
Comparative Analysis about Binding Preliminary Agreements between Brazil and United States Legal Systems
}

\author{
Marcela Carvalho Viegas \\ Duquesne University of Law, USA \\ marcelacviegas@gmail.com
}

\begin{abstract}
During the past decades the world became one globalized market in a way that every country, with few exceptions, established economic, social and political relations among then. Consequently, new legal bonds started uprising in reason of the contracts signed to support such international relations. A lot of problems would be avoided if all the countries had the same legal system and if the same laws regulated the contracts. This is not even imaginable.

Within this scenario, this research had the purpose to analyze why preliminary agreements became a crucial tool when dealing with contracts that easily involve parties from different countries and different legal systems and that were made through a process much more complex than the idea of the two parties exchanging offers, acceptance and performance. Furthermore, this paper significantly examined and compared which kinds of preliminary agreement exist and which ones attract legal responsibilities (are binding) between different countries and different legal systems. This study focused specifically in the difference between Brazil's, a Civil Law country, and Unites States', a Common Law country, legal systems. KEY WORDS: legal systems, negotiation, contract, civil cod, preliminary agreement.
\end{abstract}




\section{Introduction}

Development is the word of the century. Everything and everyone works and reacts based on the idea of the development of projects, books, startups, big companies, sustainable solutions, communication, among others. What no one sees, or what most people do not see, is that behind all of the development, all over the world, there is a signed contract or one to be signed.

The kind of negotiation done nowadays is very different from the one done some years ago. Today the contracts need to predict and to deal with a lot of variables that did not exist before. The idea of two parties exchanging proposals until another party forming the contract accepts an offer does not correspond to what happens in the complex processes to make a contract nowadays (Farnsworth 1987,1).

It is very difficult to deal with all possible circumstances, as Allan Farnsworth noted in his article:"major contractual commitments are very complex and typically set out in a lengthy document, or in a set of documents, signed by the parties in multiple copies" (Farnsworth 1987, 1). This process can take a lot of time and involve a lot of people and several "rounds" of negotiation. On this long way to make a contract, it is very common that the parties prefer to make a preliminary agreement to avoid the uncertainties of the negotiation processes, so they can discuss the points with time and insurance and with the certainty that when they finally make the final contract, this contract will correspond to the best interest of the parties and will be well accepted. The term "Preliminary Agreement" is used to refer to all kinds of documents made by the parties before the final agreement, which can be either non-binding or binding, depending on the intention of the parties, the language, the way that is made, and on a lot of other variable circumstances that the article will talk about later.

Examples of preliminary agreements are "letter of intents" [in the majority of the cases, letter of intents are not binding because they usually contain language denying the legal enforceability of the terms of the agreement], "agreement with open terms", "agreement to negotiate with good faith", and "preliminary contract" (Knutson 1991,1).

\section{Advantages and Disadvantages of making preliminary agreements in both legal systems}

It is a fact that in all agreements that involve two or more parties, no matter in which legal system, it is more than expected that each one will have his own motivation and 
objective. Considering this variable, it is necessary to focus on the outward expression that needs to be convergent (See Lucy V. Zehmer) so that the parties can put efforts together to make a contract that will satisfy them both.

Beyond the necessity of putting efforts together, in some legal systems, like the Brazilian one, good faith will be something that the parties need to have during the entire time of making a contract. In others, like the United States' one, good faith is not a request in all stages of the negotiation and of the performance of the contract; this article is going to talk about this in other further point.

In a normal situation the parties will first exchange information and an identification of each parties' interests and differences (Farnsworth 1987,2), then they will go through the major points in order to get to a point in common. To get to this convergent point, most of the time, the parties need to engage in a negotiation that can take hours, weeks or even years.

For example, when Bayer agreed to buy Monsanto in a $\$ 66$ billion deal, the deal had so many details, people involved, government bureaucracy and a lot of money that the final contract took years to be finalized.

A preliminary agreement is very useful for different purposes, for example to provide a summary of the results of the negotiation from time-to-time and to establish what has already been negotiated.

Beyond the fact that the parties will make sure that the terms discussed will not be discussed again, preliminary contracts can be useful as a guaranty that the other party really intends to make a final contract and is not merely wasting time on it. It is clear that, if one party rejects the preliminary agreement proposed by the other party, this party it is not in accordance with the negotiation. This means that for the parties to have successful contracts they should either intensify the negotiation or decide to terminate it (Knutson 1991, 2).

Another situation where the preliminary agreement can also be very valuable is when is related to a contract that precedes a big transaction. In this kind of situation, the companies cannot wait until all the paperwork is done to start to produce effects. So, they make a preliminary agreement to give them the assurance they need to start acting based on a future final contract.

Apart from all the value and utility of the preliminary agreements, be it on the Brazilian or United States' legal system, what is considered the most important consequence is that a binding preliminary agreement will, in and of itself, make sure that the property object of the contract is out of the market and assure the parties' preferences (Knutson 1991, 3). 
Unfortunately, preliminary agreements do not bring only advantages. This is why some people and mainly some companies avoid using a preliminary agreement. Among these disadvantages is the time that is spent to make the preliminary agreements, which if used to focus on the final contract could be much quicker and easier to negotiate.

For example, in the Brazilian legal system, the preliminary agreement needs to necessarily have all the legal characteristics as the final contract does, except to be made in the format as the legal one is made. In a real transaction this means that if the parties really want to be binding and wish to have a final contract, sometimes, when all the terms are discussed it is much easier to sign the final contract, even if it means needing to take extra time to make it in the legal format.

\section{What makes a preliminary agreement binding?}

As known, preliminary agreement can be binding or not. The question is what makes a preliminary agreement binding and consequently enforceable? At this point, there is going to have a big difference because in Brazil the legal system is the Civil Law, and in the United States it is the Common Law.

In the United States' legal system, be that an "agreement with open terms" or an "agreement to negotiate with good faith", the two main features important to pay attention to are the primarily reason why the parties had when they decided to make a preliminary contract and the terms existed in the agreement. The intention of the parties is set with the language and the other variables that will be used to know whether the contracts are binding or not.

Indeed, in many cases, the purpose of the parties when they do a preliminary contract is to bind the parties to such agreements. However, if one party has reasons to suspect or actually knows that the other intends not to be bound by the preliminary agreement, no contract is formed [See Restatement (Second) of Contracts 21].

One good example of preliminary agreement easily enforceable is the "Fully Formed Contract Claim", created when the parties make a complete preliminary agreement, with all terms discussed and leave nothing opened to negotiate. In this case, even if the parties want a more formal and definitive contract in the future, the future agreement is viewed as merely desirable, not necessary (Jeffries 2012, 6). So, the court will see the preliminary agreement as a definitive one (See Trowbridge v. McCaigue).

However, there are some cases where the parties makes a preliminary contract leaving some terms opened and some points to discuss, what characterizes an "agreement 
with open terms", or an "agreement to negotiate with good faith", which occurs when the parties just agree with the fact that they will continue to put efforts to negotiate all the terms of the final contract.

In both these situations (since there are some undefined terms and it is not clear whether the contract can be enforceable) when a breach of the contract occurs it is necessary to file a complaint. The court will then decide where the intent of the parties was bound and whether the contract can be enforceable. In order to make a decision, the court looks at the totality of the circumstances, considering objective signs of the parties' intent and mainly the terms until then negotiated. Normally, signs of intent like the language used, outward manifestation, drafts and previous communication between the parties are less difficult for the court to analyze, although in some cases this part can be very tricky too.

In situation like that, the biggest problem of a preliminary agreement being analyzed by the court is the existence of too many indefinite terms. This situation occurs when the contract lacks so many points that the court cannot enforce the contract: "A contract is unenforceable for indefiniteness if a court cannot adequately determine what is requires, permits, of prohibits or if no remedy can be fixed" (Burton $\&$ Andersen 1995, 358).

Beyond these two types of preliminary agreements, in the United States, it is possible to use some language that will assure that the agreement will be binding (even if the indefinite of the contract prevent the enforceability), such as a specific expression of intent or an expression making the execution of the agreement subject to the occurrence of one or more events (Knutson 1991,6).

On the other hand, on the Brazilian legal system, as a Civil Law system, the objective assumptions that decides if the preliminary agreement is binding or not, are established on the Civil Code. The article 462 on the Civil Code deals specifically with preliminary contracts and determines that in order to be binding and enforceable, the preliminary contract needs to have all essential elements that a final contract has, excepting the format.

The article 104 determines that for a contract, definitive or preliminary, to be valid it is necessary that the parties are capable of their acts (capable in this case means that the parties cannot be minors or mental incapacity); the object of the contract needs to be legal and determinable and must be made in some instrument that is allowed or not prohibited by law.

Another article that is very important when it comes to preliminary agreements is the Article 463 which determines that for a preliminary agreement be opposable against 
a third party, not related directly in the contract, this agreement needs to be notarized by a competent person.

These are all objective assumptions dictated by the Civil Code, but there are also some subjective principles that are very useful when the court analyses the existence of preliminary agreements. One of them is known as the "contractual nature" (Silva, 2015,1 ), which means that the contract must be a consequence of the mental assent and the outward expression of the parties together in only one legal action. Another one as important as the first one is known as the "principle of the social function" that determines that the individual parties' interests in the contract need to be in accordance with the social interest and in case of a conflict, the social interest should prevail.

Another subjective principle that is very important to be noticed when the parties are negotiating the contract or performing it, is the good faith. However, there is a big difference that needs to be explored when this principle is noticed in regards to the different perspectives between the Brazilian and the United States' legal system

\subsection{Good Faith as a duty}

Good faith can be analyzed in two perspectives, both subjectively and objectively. From a subjective point, good faith means to be honest with the other party including the idea of the mutual assent of the minds. From an objective point, good faith is known as a "performance obligation [that] protects the justified expectations of one party by constraining the discretion enjoyed by the other under the contract" (Burton $\&$ Andersen 1995, 367). Considering these perspectives, good faith can be considered a duty in some legal systems more than in others.

In the Brazilian legal system, good faith is adopted more in a subjective view, it is supplemented by the objective approach and it is a duty to the parties during all the negotiations and after that on the performance of the contract. As a codified legal system, the Article 422 on the Brazilian Civil Code expressly determines that "The parties are obligated to have during the negotiations and in the performance of the contracts, the principles of probity and good faith" (Brazilian Civil Code, article 422) In an objectively perspective "the good faith has three functions: the interpretative function, based on Article 113; the integration of legal business, based on Article 412, and the control of the limits of the exercise of the right, based on Article 187." (Mattos 2008, 1)

On the other hand, in the United States' legal system, "good faith" (See UCC $§ 1$-201 (19)(2016)) is used in a more objectively perspective and it is considered a duty only 
on the execution of the contract, not being necessary during the negotiations, in other words, it is applied just after the parties are bound, so they do not really influence the discussion about a contract been binding or not. Of course, it is allowed that the parties agree to such obligation including a clause that expresses the indispensability of good faith during all the phases, but this practice is not common.

\section{Types of preliminary agreements}

In the United States' legal system, as the law was created by the cases and the court's decisions, two types of preliminary agreements that can attract legal responsibility were created. They are known as "agreement with open terms" and "agreements to negotiate" (Farnsworth 1987, 1) each one of these agreements is different because of some features and the responsibility process when a breach occurs.

Differently, in the Brazilian legal system, the laws are created by the legislative body and are more "fixed". The Civil Code, published on January 10th in 2002, previews only the "preliminary contract" as an agreement to precede the final contract.

\subsection{Preliminary Agreements under the United States' Legal System}

In the United States' legal system it is difficult to know if preliminary agreements will attract legal responsibilities if a breach occurs. This happens because unless the parties make a statement expressly saying that they are bounded by the terms of the contract, only the court can decide so. The court will, only after analyzing all exiting terms of the agreement and the indefinites ones, the intention, other documents and the communication during the negotiation, decide if the preliminary agreement bounds the parties and is enforceable or not (which means that the contract is able to attracts consequences).

Some types of preliminary agreements, like the "Fully Formed Contract Claim" (Jeffries $2012,18)$ that contains all the terms and a clause that affirms the binding between the parties, are very easy to be classified by the court as an enforceable one, because there is nothing to be discussed and the intention of the parties are, normally, pretty clear. However, the majority of the preliminary agreements are not that definitive, what beget to the court the duty to analyze one by one when requisitioned.

\section{A. Agreement with Open Terms}

The first thing that it is important to clear about agreements with open terms is that they can be a preliminary one or a terminate one, and this difference occurs when the 
parties decide that after the negotiation of the terms another definitive agreement will be made.

Agreements with open terms normally are used when the parties need to continue on the negotiation to finally get to the final contract. These are agreements that normally "sets out most of the terms of the deal, and the parties agree to be bound by these terms. But they undertake to continue negotiating on other matter to reach agreement on some terms that are left open [...]"(Farnsworth 1987, 2).

As an agreement that can precedes the final one, the agreement with open terms is very useful. For example, in the situation cited before where the parties have a lot of things to negotiate and they do not want to keep coming back to the terms that are already discussed.

This kind of contract has some practically "automatic" consequences: "An agreement with open terms has two consequences. First, it imposes an obligation to carry out the deal even if the parties are unable to agree on the open terms. Second, it imposes a general obligation of fair dealing in the negotiation of the open terms" (Farnsworth 1987, 13).

On a binding perspective, the existence of "open terms" in this type of agreement can be very dangerous because the "gaps are sometimes so profound that they demonstrate the absence of the parties intent to make a commitment" (Ferriel 2014, 249). Which means that if the parties disagree about the obligation begot between them and file a complaint about it, the court is not able to "fix" it without prejudice or to create a "different" obligation. If this happens, the court will consider that the preliminary agreement is not binding.

There is another problem too. When this kind of contract is viewed on an enforceable perspective. Even if sometimes the parties' intention to be bound is clear, for example when there is a clause that previews the responsibility, the inexistence of some terms, like the subject matter of the agreement, can make the contract totally unenforceable.

\section{B. Agreement to negotiate in Good Faith}

About this preliminary agreement, it is important to do a little differentiation, between agreements to negotiate in good faith and agreements to agree. Agreements to agree are considered agreements in which the parties left some terms to be discussed in a future negotiation, usually in an indefinite one. This kind of agreement is traditionally considered completely unenforceable and unbinding (Ferriel 2014, 13). 
On the other hand, the agreements to negotiate are made by the parties that commit to put all efforts to negotiate the terms of the final contract. If after several attempts they cannot reach all the terms this agreement will, normally, be considered not binding. However, if the breach of the contract or the impossibility to get to a final contract results from a disregard of parties in negotiation or if the parties do not negotiate fairly, this contract will result in claim for damages based on the expectation of the parties (Farnsworth 1987, 21).

This difference is well by the California court: "A contract to negotiate the terms of an agreement is not, in form or substance, an 'agreement to agree.' If, despite their good faith efforts, the parties fail to reach ultimate agreement on the terms in issue the contract to negotiate is deemed performed and the parties are discharged from their obligations. Failure to agree is not, itself, a breach of the contract to negotiate. A party will be liable only if a failure to reach ultimate agreement resulted from a breach of that party's obligation to negotiate or to negotiate in good faith." (See Copeland v. Baskin Robbins 02 C.D.O.S 2533, March 19, 2002)

\subsection{Under the Brazilian Legal System}

The Civil Law legal system, the one used in Brazil, is characterized as a coded system where the law and all regulations are provided by the legislative body in a writing collection which all, including judges and authorities, must follow.

The Brazilian Civil Code is relatively new, it has only thirteen years, but if all the changes that happened since the Code was published are considered, it is possible to consider it a bit obsolete. One of the points that the Code falls short is on the classification of just one preliminary agreement, known as "preliminary contract".

\section{Preliminary Contracts}

The preliminary contracts in Brazil are classified as pre-contracts, a formal instrument signed by the parties to agree with the will that will be object to a more definitive contract after all negotiations. It is a way that the parties use to be legally bound to each other without a final contract. This kind of agreement is conceptualized as a bilateral legal business, whereby the parties compromise themselves to make a final contract. As seen in a couple point before, with the objective to make a preliminary contract, the parties must follow what the Civil Code determines. That said, to the agreement to be valid it is necessary that the parties are capable of his acts (capable in this case means that the parties cannot be minors or mental incapacity); the object of the 
contract needs to be legal and determinable and must be made in some instrument that is allowed or not prohibited by the law.

The problem here is that according to the Articles 462 and 104, to do a preliminary contract, that is going to be binding and enforceable, the agreement must have all essential elements that a final contract has, except the format. In a perspective of the idea of preliminary agreements, this does not make any sense because it is supposed to be quicker and to create a bond between the parties more easily.

After what was said, it is to conclude that in Brazil the practice of preliminary agreements are not very common unless the parties do not have time to wait for the formal format. Otherwise it is more prudent go directly to the definitive contract since the requirements are almost the same.

\section{Conclusions}

In a world that has been classified as fast and globalized, contracts are something inevitable and, so, as stated above, preliminary agreements will definitely be very useful and valuable. Unfortunately due to its main characteristic, to be preliminary, this kind of agreement in most cases will attract open terms, doubts and uncertainties. So, it is possible to conclude that the frequently asked question of whether a preliminary agreement is binding or not, regardless of which legal system, the Brazilian one or the United States' one, is always going to depend in the specific case, and in its majority will end being the court's responsibility to decide.

\section{References}

Burton, Steven J. \& Anderson, Eric G. 1995. Contractual Good Faith. Boston: Little, Brown.

Farnsworth E, Allan. 1987. Precontractual Liability and Preliminary Agreements: Fair Dealing and Failed Negotiations. 87 Colum. L. Rev. 217.

Ferriel, Jeff. 2014. Contracts. Third Edition, LexisNexis, 250.

Jeffries, Browing. 2012. Preliminary negotiations or binding obligations? A framework for determining the intent of the parties. 48 Gonz. L.Rev. 1.

Knutson, Brightwell, Reves \& Oldham. 1991. P.C, Preliminary Agreements, 29C RMMLF-INST 2.

Mattos, Karina Denari Gomes de. 2014. A aplicação do princípio de boa fé nas relações contratuais, Âmbito jurídico, http://ambitojuridico.com.br/site/?n_link=re vista_ artigos_leitura\&artigo_id $=27018$ revista_caderno $=7$. (Last view Dec, 20, 2016)

Silva, Murilo Santos da. 2015. Contratos Preliminares. ETIC 2015 - Encontro de Inic. 